\title{
Modified full-thickness resection of a small subepithelial tumor with the help of a corkscrew
}

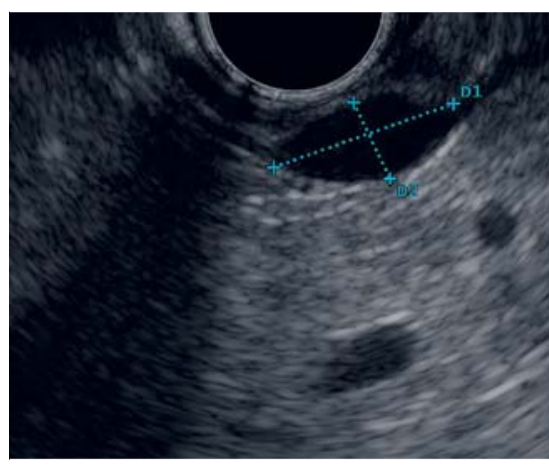

- Fig. 1 Endosonographic image of a subepithelial tumor in the proximal gastric corpus.

With the advent of endoscopic full-thickness resection (EFTR), small subepithelial tumors (SETs) became easily resectable both in upper and lower gastrointestinal tract. Several studies have suggested that complete resection of SETs is achievable in the vast majority of cases and severe complications occur only rarely [1]. Whereas technical success in the case of mucosal or submucosal lesions is easy to accomplish, for tumors arising from the muscularis propria, an $\mathrm{R} 0$ resection is more difficult to achieve by EFTR [1]. Grasping these lesions with the Twin Grasper may lead to tenting of the mucosa and submucosa, which in turn leads to incomplete removal of the SET. To overcome this technical problem, we herein present the feasibility of EFTR using a tissue-retracting helix device that was originally designed as part of the OverStitch endoscopic suturing system (Apollo Endosurgery Inc., Austin, Texas, USA).

We describe the case of a 75-year-old patient who was referred for removal of an incidental SET in the proximal gastric corpus. Endosonography suggested a small gastrointestinal stromal tumor (GIST) ( Fig.1). After the lesion had been marked ( $\triangleright$ Fig.2a), the gastroduodenal EFTR device (Ovesco, Tübingen, Germany) was mounted onto the endoscope and the helix device was advanced
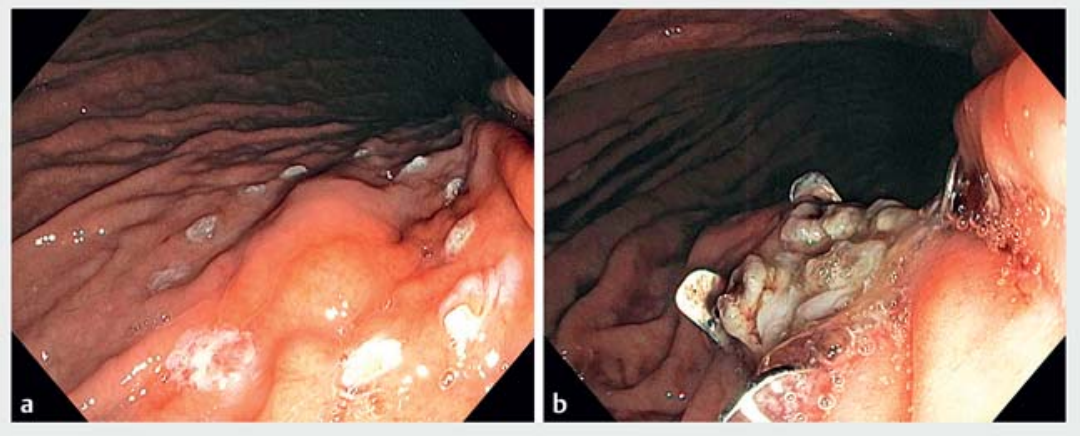

- Fig. 2 Endoscopic images showing: a the tumor after it had been marked; $\mathbf{b}$ the closed resection site.
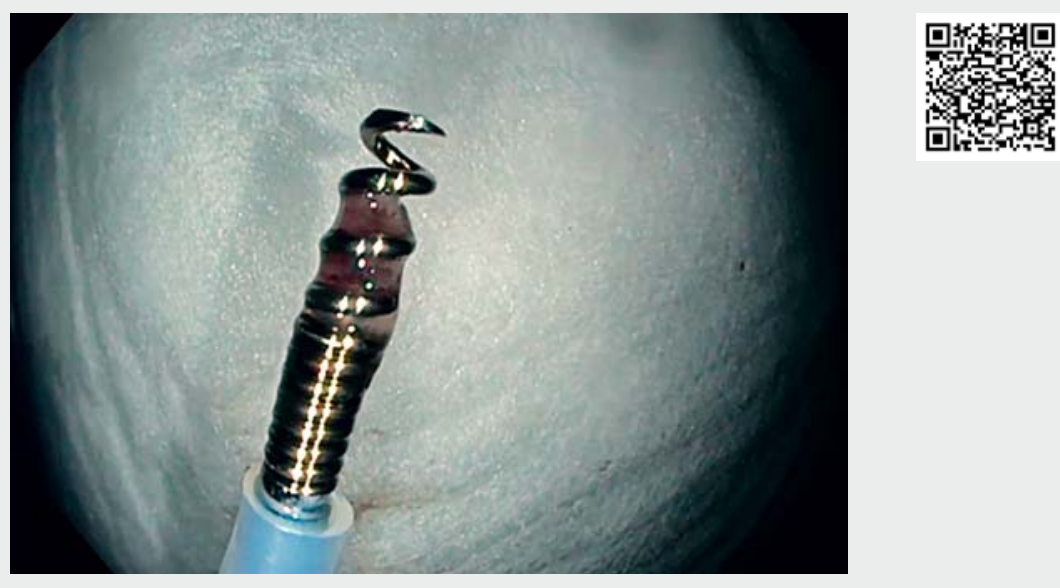

Video 1 Modified full-thickness resection of a subepithelial tumor with the help of a corkscrew device.

through the working channel. Once the endoscope was centered over the lesion, it was gradually punctured with the helix; the device was then manually rotated (like a corkscrew), resulting in tissue approximation. After this "fixation" procedure, it was easy to retract the lesion into the cap using gentle suction. The SET was then resected in the usual fashion, with adequate closure of the resection site ( $>$ Fig. 2 b; $\triangleright$ Video 1 ). The resected specimen ( $\triangleright$ Fig. 3 ) was shown histologically to be a completely resected leiomyoma.

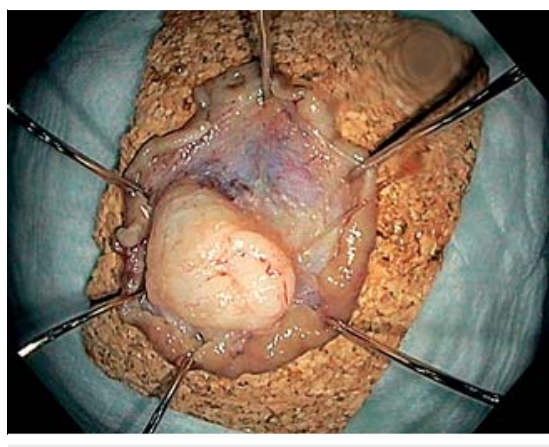

Fig. 3 Photograph of the resected tumor. 
In summary, resection of a SET arising from the muscularis propria using the helix device is technically feasible and may overcome the risk of incomplete resection. Further studies are, however, needed to support this hypothesis.

Endoscopy_UCTN_Code_TTT_1AO_2AG

\section{Competing interests}

The authors declare that they have no conflict of interest.

The authors

Bernhard Morell, Fritz Ruprecht Murray, Frans Olivier The, Simon Bütikofer, Christoph

\section{Gubler}

Department of Gastroenterology and

Hepatology, University Hospital Zurich, Zurich,

Switzerland
Corresponding author

\section{Christoph Gubler, MD}

Department of Gastroenterology and Hepatology, University Hospital Zurich, Raemistrasse 100, 8091 Zurich, Switzerland christoph.gubler@usz.ch

\section{Reference}

[1] Meyer B, Schmidt A, Glaser N et al. Endoscopic full-thickness resection of gastric subepithelial tumors with the gFTRD-system: a prospective pilot study (RESET trial). Surg Endosc 2019. doi:10.1007/s00464019-06839-2
Bibliography

DOI https://doi.org/10.1055/a-1073-7344

Published online: 20.12.2019

Endoscopy 2020; 52: E217-E218

(c) Georg Thieme Verlag KG

Stuttgart · New York

ISSN 0013-726X

\section{ENDOSCOPY E-VIDEOS \\ https://eref.thieme.de/e-videos}

口回 Endoscopy E-Videos is a free

access online section, reporting

自: on interesting cases and new

techniques in gastroenterological

endoscopy. All papers include a high

quality video and all contributions are

freely accessible online.

This section has its own submission

website at

https://mc.manuscriptcentral.com/e-videos 